\begin{tabular}{|c|l|}
\hline Title & Equal Employment Opportunity Law and the gender wage gap in Japan : A cohort analysis \\
\hline Author(s) & A be, Yukiko \\
\hline Citation & $\begin{array}{l}\text { Journal of A sian Economics, 21(2), 142-155 } \\
\text { https:/doi.org/10.1016/.asieco.2009.12.003 }\end{array}$ \\
\hline Issue Date & 2010 \\
\hline Doc URL & http://hdl.handle.net/2115/58482 \\
\hline Type & article (author version) \\
\hline File Information & abe_cohortwage.pdf \\
\hline
\end{tabular}

Instructions for use 


\title{
Equal Employment Opportunity Law and the Gender Wage Gap in Japan: A Cohort Analysis*
}

\author{
Yukiko Abe ${ }^{* *}$ \\ Graduate School of Economics and Business Administration, \\ Hokkaido University
}

October 2009

\begin{abstract}
In this article, I perform a cohort-based analysis of the female-to-male wage gap using aggregate data in Japan from 1975 to 2005. While the inter-cohort closing in the gender wage gap is apparent, the convergence is smaller when the gap is calculated for each level of education. This pattern suggests that a certain portion of the gender wage convergence is due to changes in the educational composition of the workforce. I find that educational composition changes played a larger role in closing the pay gap for younger cohorts than it did for older cohorts. Highly educated women who entered the labor market after the enactment of the Equal Employment Opportunity Law gained in that they had more regular full-time employment but did not experience wage gains relative to their male counterparts.
\end{abstract}

Keywords: Female-to-male wage gap; Cohort; Equal Employment Opportunity Law JEL Classification Numbers: J16, J21, J31, J78

\footnotetext{
*I thank Yoshio Higuchi, Haruhiko Hori, Dean Hyslop, Akira Kawaguchi, and seminar participants at Hokkaido University for comments. Remaining errors are my own. Earlier versions of this paper were presented at the ESRI International Collaboration Projects 2007 Meeting (March, 2008) and the 2008 Fall Meeting of the Japanese Economic Association at Kinki University (September, 2008). This research is partly supported by ESRI International Collaboration Projects 2007 (Toward the Sustainable Growth and the Financial Reconstruction in the Aging Society); the Japanese Ministry of Education, Science, Sports and Culture Grant to Hosei University on International Research Project on Aging (Japan, China, Korea: FY2003 to FY2007); and the Japan Society for Promotion of Science Grant-in-Aid for Scientific Research (Grant Number B-19330053 and C-20530188).

** Corresponding author: Graduate School of Economics and Business Administration, Hokkaido University, Kita 9 Nishi 7, Kita-ku, Sapporo, 060-0809 JAPAN Phone 81-11-706-3860, Fax 81-11-706-4947, Email: abey@econ.hokudai.ac.jp
} 


\section{Introduction}

The gender wage gap has narrowed steadily in Japan for the past several decades. The gender wage ratio, measured as the ratio of female hourly wage to male hourly wage, was 0.60 in 1980 , but it was 0.70 in $2004 .{ }^{1}$ In spite of this improvement from the 1980s, the ratio in Japan is lower than in most industrialized countries (Blau et al. 2006, Table 11-4). In this article, I examine how the Equal Employment Opportunity Law (EEOL) for men and women in Japan, first enacted in 1986 and then enhanced in 1999, has affected the female-to-male wage gap. ${ }^{2}$ To explore that question, aggregate data from seven points in time from 1975 to 2005 are used.

The ways in which the EEOL affected employment and wages of female workers, especially at different stages of the lifecycle, has not been fully understood in previous research. In this article, I perform a cohort-based analysis of the female-to-male wage gap. Analysis by cohorts is particularly important because the EEOL is assumed to have expanded employment opportunities for younger cohorts of women who finished schooling and entered the labor market after the EEOL's enactment in 1986 (Edwards 1988, 1994; Cannings and Lazonick 1994; Blau et al. 2006; Abe 2009a). I call those cohorts who finished schooling after 1986 "post-EEOL cohorts" and those cohorts who finished schooling before the EEOL enactment "pre-EEOL cohorts." How much the post-EEOL cohorts of women gained in terms of wages compared to cohorts preceding them is the primary concern of this article. ${ }^{3}$

\footnotetext{
${ }^{1}$ These estimates are based on the author's calculation from the Basic Survey of Wage Structure (BSWS). In 2005, the female-to-male wage ratio fell slightly from its level in 2004.

2 Beginning in 1986, the EEOL prohibited discrimination against women in hiring, training, and promotion, but the law at that time asked employers to voluntarily comply. The revised law in 1999 explicitly prohibited discrimination. The EEOL was further enhanced in 2007, when discrimination against both sexes was prohibited; before 2007, only discrimination against women was prohibited.

3 The importance of considering cohort in understanding gender wage convergence is pointed out in
} 
It turns out that the inter-cohort closure in the female-to-male wage gap is rather limited once educational attainment is controlled for. Therefore, the obvious causes for the narrowing overall gender wage gap are changes in the educational composition of the workforce. Significant changes in worker composition took place in the Japanese labor market from 1975 to 2005. Among regular full-time employees, increasing educational attainment and "aging” occurred during this period for both men and women. ${ }^{4}$ It is shown that the compositional changes in education explain a greater portion of the improvement in the gender wage gap for younger cohorts, while they played a smaller role for older cohorts. Furthermore, it is shown that groups of women who gained in terms of regular employment did not gain in relative wages: for instance, post-EEOL cohorts of university graduate women became more likely to work in regular full-time jobs, while their wages did not increase relative to their male counterparts.

This paper is organized as follows. In Section 2, data are explained and gender gap measures are introduced. Section 3 reports trends in the female-to-male wage gap and employment gap as raw tabulations. Section 4 presents the results from regression analysis. Section 5 discusses the possible influence of worker composition on the wage gap. Section 6 concludes.

\section{Data and definitions}

\subsection{Wage data}

I use aggregate data of the Basic Survey of Wage Structure (BSWS) for years

O’Neill and Polachek (1993).

${ }^{4}$ The regular full-time workforce is the set of workers whose employment contract does not set a fixed term length and, in most cases, whose regular work schedules are 40 hours per week. 
1975, 1980, 1985, 1990, 1995, 2000, and $2005 .^{5}$ The BSWS is a survey of earnings and hours conducted every year by the Ministry of Health and Welfare. It is the most widely used source of data regarding wages for empirical studies of the Japanese labor market. The published data I use contain cell-mean data of wages, hours, bonuses, and tenure (the length of service at the employer), along with the estimated number of workers for each cell, where the cell is defined by sex, age group (5-year interval), and education (4 levels). ${ }^{6}$ The hourly wage rates for men and women are calculated by dividing monthly base earnings (shoteinai kyuyo) by monthly hours (shoteinai-jitsu rodo jikan). The earnings do not include bonuses or overtime pay, and hours do not include overtime hours. ${ }^{7}$ The analysis is limited to wages of male and female full-time employees. It does not include part-time employees because the BSWS does not collect information on the educational attainment of part-time employees.

The use of published aggregate data certainly has limitations. Most notably, since the cell-mean wages are used, any questions that are related to wage distributions cannot be addressed. On the other hand, although some researchers do have access to microdata of the BSWS, I believe tracing wage changes for 30 years is only possible with aggregate data, which is what I pursue in this article.

In the rest of the article, I use the following measure of the gender wage gap, which is 1 minus the gender wage ratio:

\footnotetext{
${ }^{5}$ It is still difficult to use microdata of survey data collected by the Japanese government for research purposes. A recent study by Kambayashi et al. (2008) uses microdata of BSWS and contains a detailed description of the BSWS survey method.

${ }^{6}$ The four levels of education are junior high school graduate (9 years of compulsory schooling), senior high school graduate (12 years of schooling), junior college graduate (usually 14 years of schooling, including some vocational and technical schools), and university graduate (16 years or more of schooling, including graduate education).

${ }^{7}$ I performed a similar analysis using a wage measure that includes bonuses and overtime hours. The results are shown in Table A1. In deriving the hourly wage including bonuses, the bonus values are taken from the next survey year because information on the bonus amount is collected for the previous calendar year in the BSWS.
} 


$$
\text { WageGap }=1-\frac{\text { mean Female Wage }}{\text { mean Male Wage }} \text {. }
$$

This measure takes a higher value when the disparity between female wages and male wages is larger. The reason for using the WageGap variable is that it can be easily decomposed into two terms: (a) the term representing educational composition of female and male workers and (b) the term representing the gender wage gap within each education group. Results from this decomposition are presented in Section 5.2. The WageGap measure in Eq. (1) is called the "gender wage gap” in the rest of the article.

\subsection{Employment data}

The BSWS data are not suited for analyzing participation behavior since the survey is conducted only for workers. The Employment Status Survey (ESS, Ministry of Internal Affairs and Communications), which is a household survey, allows me to examine how participation in regular full-time jobs changed over time and across cohorts. I use the published, aggregate data of the ESS from 1987 to 2007, the years for which the published tables contain information disaggregated by education and age. Using the data from five points in time, I estimate the gender gap in the regular employment ratio. The regular employment ratio is defined as

$$
R E R=\frac{\text { Number of Regular Employees }}{\text { Population }}
$$

where the "Number of Regular Employees" is the sum of regular employees and executives and the "Population" is the population for each cell, defined by birth year, education, and age group..$^{8}$ The employment gap in this article is defined similarly as WageGap, as follows:

\footnotetext{
${ }^{8}$ I include executives of private corporations in the set of regular employees. Corporate executives are included because many are promoted to the position from positions as regular employees and because many of those promoted are male university graduates.
} 


$$
R E R G a p=1-\frac{R E R_{\text {female }}}{R E R_{\text {male }}} .
$$

This measure is called "gender employment gap" in the rest of the article.

\section{Trends in the female-to-male wage gap and the employment gap}

\subsection{Gender wage gap}

Figure 1 plots the female-to-male wage gap against age for the sample that pools all educational groups. ${ }^{9}$ As the figure shows, the gender wage gap widens as workers age. The figure also shows that there have been significant wage gains for female employees of recent cohorts as compared to their male counterparts. However, the patterns are quite different for the different levels of education.

Figure 2 graphs the gender wage gaps separately for level of education. As noted in previous studies (Hori 1997; Kawaguchi 2005), the female-to-male wage gap is low for the more educated. For example, in 2005, the mean of the wage gap for senior high school graduates was 0.31 , while it was 0.16 for university graduates. ${ }^{10}$ Significant inter-cohort improvement in the female-to-male wage gap is observed in Figure 1, where workers of all educational groups are pooled together, but much less convergence is observed when the gap is calculated by level of education. These patterns suggest that the closing of the female-to-male wage gap is driven by changes in educational composition of the female and male full-time workforce.

\footnotetext{
${ }^{9}$ To make the inter-cohort differences clear in the figures, the gaps are plotted for the subset of cohorts in the sample. The regression analyses use all cohorts, including the ones not shown in the figures.

${ }^{10}$ Blau et al. (2006, Table 5-8) report that in the United States, the gender earnings ratio is lower (gender earnings gap is higher) for those with 4 or more years of college education than for the less educated. Mulligan and Rubinstein (2008), on the other hand, report a somewhat different pattern. They present the wage gaps of married women vs. married men with advanced degrees in the United States. They show that the gender wage gap for this group is much narrower than it is for college graduates and high school graduates. Baker et al. (1995) report that in Canada, the female-to-male earnings gap is smaller for the more educated.
} 
Figure 2 also shows that the improvement of female wages is greater for the less educated than for university graduates. In terms of age patterns of inter-cohort change, Figure 2 suggests that the gender wage gap closed more significantly for older ages than for young ages. For example, for senior high school graduates aged 25-29, the fall in the female-to-male wage gap between the 1956-1960 birth cohort and the 1976-1980 birth cohort is 0.018 . For senior high school graduates aged $40-44$, the fall from the 1941-1945 birth cohort to the 1961-1965 birth cohort is 0.097.

It has been expected that the EEOL expanded women's employment in workplaces that were traditionally male-dominated. Several previous studies have found that young women of recent cohorts in Japan acquired more 4-year university education than older cohorts did and that they majored in fields that are more oriented toward ambitious career plans (Edwards 1994; Edwards and Pasquale 2003). If the post-EEOL cohorts of women had more human capital when they entered the labor market, then later cohorts of women are likely to perform better than previous cohorts. In other words, they are more likely to be employed in "better positions," or their wage levels are likely to be higher. The average wage data do not necessarily conform to such a hypothesis, however, because the gender wage gap did not narrow for post-EEOL cohorts.

\subsection{Gender employment gap}

The trends in gender wage gaps shown in the previous section might well be related to the extent to which the gender differences in employment in regular full-time work over the period.

Several previous studies point out a possible link between participation 
behavior and the gender wage gap. Blau and Kahn (2006) show that changes in participation over time affected the development of the gender wage gap in the United States. Specifically, they show that a part of the slower gender wage convergence in the 1990s than in the 1980s is attributed to the ways in which female participation changed over the two periods. ${ }^{11}$ Olivetti and Petrongolo (2008) use cross-country data and show that the gender wage gap tends to be higher in countries where women's participation is high and argue that much of the cross-country differences are explained by the different degree of selection into the labor market across countries. Mulligan and Rubinstein (2008) argue that the direction of selection into employment changed over time in the United States and that this change explains the gender wage convergence.

All of these papers show that changing participation rates, especially that of women, potentially affect the development of female-to-male wage gaps. In the context of this article, the implications from these studies would be that changes in the gender wage gap are negatively correlated with changes in the gender employment gap, assuming positive selection into employment. In principle, whether selection is positive or negative is an issue to be tested; however, it is plausible to think that selection is positive in the present application because the focus of this article is regular full-time employment, which is considered to have become more and more selective in recent years.

Figure 3 shows the gender gap in regular employment for selected cohorts

\footnotetext{
${ }^{11}$ Goldin (1989) shows that, in the United States, the labor market experience of working women did not increase much over the period when women's participation rose. This observation is also consistent with a stable female-to-male wage gap over the period when women's participation rose. Hunt (2002) shows that the gender wage gap in East Germany narrowed by 10 percentage points between 1990 and 1994, although it accompanied a large decline in employment of low-skilled women.
} 
separately by level of education. ${ }^{12}$ The vertical axis measures RERGap, which takes larger values when the RER of men and women are far apart. The gender employment gap narrowed for university graduates, while the closing is not so obvious for the less educated: in fact, the gap for junior high school graduates widened. Results from regression analysis that quantifies the inter-cohort changes are presented in the next section.

In summary, Figure 2 indicates that wage gains (compared with male employees of the same cohort with the same level of education) are greater for the less-educated group and pre-EEOL cohorts. Therefore, the groups who gained in terms of an increase in regular employment did not gain in terms of wages, while the groups that did not gain in terms of employment experienced an increase in relative wages. Thus, the impact of the EEOL was complex and not uniform across different dimensions.

\section{Regression analysis}

\subsection{Gender wage gap regressions}

The regression equation for analyzing the cohort-based gender wage gap is specified as follows:

$$
\text { WageGap }_{a, c}=\delta_{c}+\eta_{a}+X \beta \text {, }
$$

where the dependent variable is the female-to-male wage gap, $\delta_{c}$ is a set of cohort

\footnotetext{
${ }^{12}$ It is important to note that female-male comparisons of the junior high school and junior college group are different from others, especially when one compares outcomes of the whole population (instead of outcomes for workers only). For junior high school graduates, the fraction in the population is low, and it is more so for recent cohorts, which could make the estimates less stable than those of other groups. For the junior college group, women are the majority, and the number of men in this category is small (Table A2), which may make the female-male comparison for this group different from others. Thus, I assess that the across-gender comparison is more accurate for senior high school graduates and university graduates.
} 
effects, and $\eta_{a}$ are age effects. The regressions are estimated by weighted least squares using the hours supplied by workers in each cell (men and women) as weights. ${ }^{13}$ The results are shown in Table 1 . Column (1) of Table 1 reports results for four education groups pooled together, without including the education dummies. The cohort effects indicate that the female-to-male wage gap has narrowed (the dependent variable takes a smaller value) for more recent cohorts; the coefficients of cohort dummies are always lower for more recent cohorts. However, when education dummies are included (column (2)), the inter-cohort improvement is not as significant as in column (1). The magnitude of the improvement is not as large as in column (1), and the coefficients of several cohorts are not lower than the cohort born 5 years earlier.

Columns (3) to (6) of Table 1 report regression results estimated separately for four educational groups. The coefficients of cohort dummies indicate that across-cohort improvement in the gender wage gap is more significant for older cohorts. It is interesting to note that women of pre-EEOL cohorts experienced wage gains. The post-EEOL cohorts, on the other hand, did not gain much relative to the 1956-1960 birth cohort (the base group for cohort dummies), for all education groups. The coefficients of cohort dummies attached to the post-EEOL cohorts are small in magnitude, and many of them are not statistically different from zero. Some of the point estimates are even positive, showing an increase in the gap. The pattern of cohort effects also shows that inter-cohort improvement is smaller for junior college and university graduates than for junior high school and senior high school graduates.

${ }^{13}$ Regression samples are restricted to cohorts that have at least two observations per cohort. Because (potential) university graduates are still in school at ages 20-24, I omit observations of the age 20-24 category from the university graduate sample in the gender employment gap regressions in Table 3. To make the gender wage gap regressions and employment gap regressions consistent, I omit this categoty from the wage gap regressions as well. Because of these, age 20-24 dummy is not included in regressions for university graduates, and the 1976-1980 birth cohort is excluded from the university sample. 
Kawaguchi (2005) finds that the extension of tenure is the main cause for the narrowing gender wage gap between 1990 and 2000. To investigate the extent of such effects in a cohort context, I run regressions that add the female-to-male average tenure ratio (the average female tenure divided by the average male tenure). The results are shown in Table 2, for regressions estimated separately by education. The coefficients of the relative tenure variable are not statistically significant for all of the four education groups. After including the relative tenure variable, the inter-cohort improvement in the gender wage gap is still more obvious for less-educated, pre-EEOL cohorts than for others.

\subsection{Gender employment gap regressions}

Next, I turn to the regression analysis of the employment gap using the ESS data. Since the timing of the ESS data does not coincide with that of the BSWS data and the time period covered in the two data are different, I set the base group of cohort dummies in the two regressions as close as possible: for the employment gap, the 1958-1962 cohort is the base group, while it is the 1956-1960 cohort for the wage gap. The dependent variable for the regression is the RERGap. The explanatory variables are cohort dummies, age dummies, and education dummies. Results are reported in Table 3.

As suggested in Figure 3, the inter-cohort improvement in the gender employment gap differs across education groups. University graduates of post-EEOL cohorts (born after 1963) are the only ones that experienced a robust decline in the gender employment gap. For post-EEOL cohorts of other education groups, the coefficients of cohort dummies are mostly small in magnitude and are statistically insignificant. For junior high school graduates of post-EEOL cohorts, the coefficients are positive, which 
means that the employment gap rose for this education group. These patterns are consistent with the findings that the EEOL advanced the regular employment of post-EEOL cohorts of university graduate women at young ages but did not increase regular employment for less-educated women or for university graduate women of pre-EEOL cohorts (Abe 2009a). ${ }^{14}$

Taken together, relative wage gains are most obvious for the pre-EEOL cohorts of the less-educated group and smallest for the post-EEOL cohorts of university graduates. On the other hand, the gender gap in full-time employment narrowed for recent cohorts of university graduates, while it did not narrow for less-educated groups. Therefore, across-education differences in changes in the wage gap and in the full-time participation gap are consistent with the hypothesis presented in Section 3.2: the change in the gender wage gap is negatively related to changes in the gender employment gap. Yet, the time series change in the gender wage gap for the fixed education group is not entirely consistent with the hypothesis. Tables 1 and 3 suggest that the employment gap narrowed for recent cohorts of university graduate women, yet the gender wage gap stayed essentially constant, instead of rising. An alternative explanation might be that the post-EEOL cohorts in the data are aged 44 or younger, and for this age group, the gender wage gap was not large even before enactment of the EEOL; thus, women did not experience relative wage gain. ${ }^{15}$

\footnotetext{
${ }^{14}$ Abe (2009a) also shows that the proportion of university graduate women who work as regular employees at older ages remained almost the same for the pre-EEOL cohorts and the post-EEOL cohorts. For instance, for university graduates aged 40-44, the $R E R$ was 38.4 percent for the earliest post-EEOL cohort (born 1963-1967), while the same ratios were 36-38 percent for the three pre-EEOL cohorts (born 1948-1962). In that sense, the EEOL has advanced women's regular employment for young ages but not for older ages.

${ }_{15}$ I run wage gap regressions for years from 1987 to 2007 (at 5-year intervals) by including the $R E R G a p$ variable as an explanatory variable (the results are not shown). When regressions are estimated separately for each education group, the coefficients of the RERGap variable are negative, but they are never statistically significant at the 5 percent level. Furthermore, the general pattern of
} 
In summary, the EEOL did not have a large impact on the relative wages of female university graduates for whom regular employment increased most. This is not surprising because university graduate women who worked as regular full-time employees in the past received wages close to those of their male counterparts. The EEOL, which increased the number of educated women working at such wage levels, did not have a significant impact on increasing wages of those female regular employees.

\section{Role of the changes in educational composition of the workforce}

\subsection{Trends in worker composition}

Figures 1 and 2 indicate that although inter-cohort improvement in the wage gap is observed for the full-time workforce as a whole, the gap has not fallen as much when calculated for each level of education. The regression estimates also confirm that inter-cohort improvement in the gender wage gap is small when regressions are estimated separately for educational attainment. These suggest that the changes in the educational composition of the workforce should be a key determinant for the narrowing gap of male and female wages.

Figures 4 and 5 show the share of working hours of regular full-time employees supplied by workers of each education-age pair, separately for male and female workers. The share of university graduates (16 or more years of schooling) increased for both males and females, while the share of junior high school graduates (9 years of compulsory schooling) fell, especially for men.

The most significant change in worker composition shown in Figures 4 and 5 is the decline of the share of young workers among women. For example, the share of coefficients of cohort dummies does not change because of the inclusion of this variable. 
hours supplied by workers aged 20 to 24 was 33 percent in 1975, while the same figure was 14 percent in 2005. The female, regular full-time workforce used to consist mainly of senior high school graduate women aged less than 30. By 2005, however, the share of such workers in the female regular workforce decreased, and the proportion of female workers with more education and higher ages increased. ${ }^{16}$ The tabulations of Figures 4 and 5 are for the cross sections of years 1975 and 2005 and are not shown in a format to follow cohort experiences. They, nevertheless, illustrate the significance of compositional changes.

What caused the change in educational composition of the regular full-time workforce, the set of workers analyzed here? There are two main reasons. One is obviously the fact that the educational attainment of the population has improved. ${ }^{17}$ The other is that the regular full-time workforce has become more selective in the sense that it has become more difficult for the less educated to engage in regular full-time work. The fact that young men and women lost regular employment during the recession in the 1990s has been pointed out (Genda 2003). The loss of regular employment is not limited to the young, however: it occurred for middle-aged men with less education as well (Genda 2006; Abe 2009b). ${ }^{18}$

\footnotetext{
${ }^{16}$ It is important to note that this dramatic change is most apparent for full-time employees. For female part-time employees, although educational advancement took place, the extent is modest compared to full-time employees.

17 The educational composition of cohorts of men and women are shown in Table A2.

${ }^{18}$ Note that Figures 4 and 5 show shares in hours supplied, instead of number of workers. This is motivated by the fact that the hourly wages used in this paper are weighted averages of hourly wage rates of individual workers, in which hours supplied by individual workers are used as the weight. This is the only measure of hourly wages available using aggregate data. Shares in hours supplied are determined by hours supplied by individual workers as well as number of workers. In fact, working hours changed significantly from 1975 to 2005, and the pattern of changes differs across education groups. However, its effect on the gender wage gap is not large because the pattern of changes is similar between male and female workers within each education group.
} 


\subsection{Quantifying the role of educational composition}

The main focus of the present analysis is the impact of the educational composition on the gender wage convergence across cohorts. In order to understand the separate contribution of the educational advancement and the narrowing gender wage gap within education group, I make the decomposition explained below. Let $\theta_{\sec a}$ be the proportion of education group $e$ for birth cohort $c$ at age $a$ for sex $s$, let $w_{\sec a}$ be the wage rate for education e for cohort c at age a for sex $s$, and let sex subscripts be $M$ for male and $F$ for female. Then, the gender wage gap defined in Eq. (1) for cohort $c$ at age $a$, WageGap W,a $_{\text {, }}$ is

$$
\text { WageGap }_{c, a}=\frac{\sum_{e}\left(w_{M e, c, a} \cdot \theta_{M e, c, a}-w_{F e, c, a} \cdot \theta_{F e, c, a}\right)}{\sum_{e} w_{M e, c, a} \cdot \theta_{M e, c, a}} \text {. }
$$

Let $w_{e, c, a}$ be the mean wage for all workers (male and female) with education $e$, cohort $c$, and age $a$. Then Eq. (5) is decomposed as:

$$
\begin{aligned}
& \text { WageGap }_{c, a}= \underbrace{\frac{\sum_{e} w_{e, c, a}\left(\theta_{M e, c, a}-\theta_{F e, c, a}\right)}{\sum_{e} w_{M e, c, a} \cdot \theta_{M e, c, a}}}_{\text {EducComp term }} \\
&+\underbrace{\left.\sum_{e}\left\{\left(w_{M e, c, a}-w_{e, c, a}\right) \cdot \theta_{M e, c, a}+\left(w_{e, c, a}-w_{F e, c, a}\right) \cdot \theta_{F e, c, a}\right)\right\}}_{\text {WithinGap term }} \\
& \sum_{e} w_{M e, c, a} \cdot \theta_{M e, c, a}
\end{aligned} .
$$

In Eq. (6), the first term captures the effect of gender differences in educational attainment on the WageGap: this term is called EducComp in the following. The remaining term (the second line) is the sum of the gender gap within each education group, which is called WithinGap. The two components, along with the share of the 
EducComp term in WageGap, are shown in Table 4. The WithinGap component is much larger in magnitude than the EducComp component. However, the WithinGap component became smaller, and the share of the EducComp component rose for recent cohorts. $^{19}$

In order to analyze changes in WageGap from adjacent cohorts, I take the difference between WageGap $_{a, c}$ and WageGap $_{a, c-5}$, arriving at

$$
\Delta \text { WageGap }_{c, a}=\text { WageGap }_{c, a}-\text { WageGap }_{c-5, a}=\Delta \text { EducComp }_{c, a}+\Delta \text { WithinGap }_{c, a} \text {, }
$$

where the $\Delta$ prefix refers to the difference between cohort c and cohort c-5 (e.g., $\left.\Delta \operatorname{EducComp}_{c, a}=\operatorname{EducComp}_{c, a}-\operatorname{EducComp}_{c-5, a}\right)$.

Table 5 lists each component in the two components in Eq. (7). The negative value means the WageGap narrowed from the cohort born 5 years earlier with the same level of schooling. Overall, $\Delta$ WageGap $_{c, a}$ are mostly negative, implying that the gender wage gap narrowed continuously from cohorts born earlier. Although there are some exceptions, $\Delta E$ EucComp $p_{c, a}$ tends to be positive for cohorts born before 1960, meaning that educational composition moved in a direction to increase the gender wage gap for these cohorts. This is because for these cohorts the educational composition of male workers improved. On the other hand, for cohorts born after 1961 most

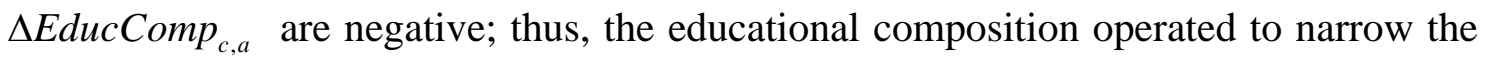
gender wage gap.

Most estimates of $\Delta$ WithinGap $_{c, a}$ are negative, and are larger than the

\footnotetext{
${ }^{19}$ It is important to note that the magnitude of the WithinGap term is also affected by $\theta$ 's, so what it measures is not entirely independent from worker composition.
} 
$\Delta$ EducComp $_{c, a}$ of the same cohort-age pair in absolute value, which implies that the inter-cohort closing in the gender wage gap is caused by the closing gender wage gap within the education group. However, the magnitude of this component shrank over time: the absolute value of $\Delta$ WithinGap $_{c, a}$ is around 0.05 for cohorts born before 1960 , while it is 0.01 or smaller in many of the cases for cohorts born after 1961.

In summary, the gender wage gap closed continuously across cohorts. For cohorts born before 1960, the main cause was the closing wage gap within education groups. For cohorts born after 1961, the closure in the within-education gap slowed, and the educational composition made more contributions to narrow the gap. The inter-cohort convergence in the gender wage gap shown in Figure 1 is caused by two separate mechanisms. For older cohorts, relative wage gains to female workers played the main role. For post-EEOL cohorts, the relative gains in pay are small. However, the educational composition of female workers improved, so the overall pay gap still narrowed.

\section{Discussions and Conclusions}

The analysis in this article shows that the female-to-male wage gap in Japan narrowed for more recent cohorts. For young cohorts, educational advancement of the female full-time workforce contributed more to narrowing the overall gender wage gap than did the improvement in relative pay. It is interesting to note that the closing in the gender wage gap occurred for the group of women for whom regular employment did not increase. University graduate women experienced increases in full-time employment, but their wages did not rise much relative to male university graduates. Young women 
with a junior or senior high school education became less likely to work in regular full-time employment. However, wages of female junior and senior high school graduates, especially in older groups, seem to have improved relative to their male counterparts.

An important caveat of the present analysis is that the data do not include part-time workers. This omission is inevitable because the BSWS data do not collect educational attainment of part-time workers. It is nonetheless important to note that since more women work as part-time employees than men and part-time wages are lower than full-time wages, the gender gap in this paper understates the real gender wage gap. $^{20}$

How do these results in this paper differ from other studies that have examined the gender wage gap in Japan? Hori (1998) uses microdata of the BSWS in 1986 and 1994 to perform the Juhn-Murphy-Pierce (JMP) type decomposition (Juhn et al. 1991) similar to the analysis done by Blau and Kahn (1997) for the United States. Kawaguchi (2005) uses microdata of the BSWS in 1990 and 2000 to perform the JMP decomposition. These two studies, while using a similar technique, reach rather different conclusions. Specifically, Hori concludes that the unobserved effect is the most significant cause for the decline in the gender wage gap and does not find that the increase in tenure contributed to the narrowing of the gender wage gap. Kawaguchi, on the other hand, finds that extension of tenure is the most significant cause for convergence. The timing of the data used in the two studies is 6 years apart, which may explain the different results. For one, if the impact of the EEOL materializes as time

\footnotetext{
${ }^{20}$ According to the $2007 \mathrm{ESS}$, the proportion of non-regular workers (employees who are not regular workers, including part-time workers) among wage-salary earners aged 25-54 was 13 percent for men but 51 percent for women. The existing statistics of the part-time/full-time wage gap for female workers range from 30 to 40 percent.
} 
passes, the pattern of the gender wage gap may differ depending on the phases of that development. Alternatively, it is possible that the compositional changes in the workforce that took place between these years contributed to the differing results.

Kawaguchi and Naito (2006) use microdata of ESS and employ a bound technique to find the upper and lower bounds for the gender wage convergence. They account for composition in modeling participation decisions. However, none of these analyses is based on cohorts, so existence (or non-existence) of cohort effects has not been identified.

Young, educated women increased participation in full-time employment after the enactment of the EEOL. However, the EEOL may have benefited another group of women, namely older women with less education, in terms of wages. The long-term consequences of the EEOL is a topic for further study.

\section{Appendix}

Table A1 reports regression results from using an alternative gender wage gap measure. In deriving the alternative measure, the hourly wages are calculated including bonuses and overtime pay in earnings, and including overtime hours in total hours supplied. Table A2 shows the educational composition of cohorts.

\section{References}

Abe, Yukiko. (2009a) “The Equal Employment Opportunity Law and labor force behavior of women in Japan.” Mimeo, Hokkaido University, available at http://www.econ.hokudai.ac.jp/ abe/workingP/yukiko_abe_EEOL_LF.pdf

Abe, Yukiko. (2009b) “A cohort analysis of male labor supply in Japan.” Mimeo, 
Hokkaido University, available at

http://www.econ.hokudai.ac.jp/ abe/workingP/male_ls.pdf

Baker, Michael, Dwayne Benjamin, Andree Cegep, and Mary Grant. (1995) “The Distribution of the Male/Female Earnings Differential, 1970-1990.” Canadian Journal of Economics 28(3), 479-501.

Blau, Francine D., Marianne A. Ferber, and Anne E. Winkler. (2006) The Economics of Women, Men, and Work, Fifth Edition, Pearson, Prentice Hall.

Blau, Francine D. and Lawrence M. Kahn. (1997) "Swimming Upstream: Trends in the Gender Wage Differential in the 1980s.” Journal of Labor Economics 15(1), Part $1,1-42$.

. (2006) The US gender pay gap in the 1990s: Slowing convergence? Industrial and Labor Relations Review 60(1), 45-66.

Cannings, Kathleen and William Lazonick. (1994) "Equal Employment Opportunity and the “Managerial Women” in Japan.” Industrial Relations 33(1), 44-69.

Edwards, Linda N. (1988) "Equal Employment Opportunity in Japan: A View from the West.” Industrial and Labor Relations Review 41(2), 240-250.

Edwards, Linda N. (1994) “The status of women in Japan: Has the Equal Employment Opportunity Law made a difference?” Journal of Asian Economics 5(2), 217-240.

Edwards, Linda N. and Margaret K. Pasquale. (2003) "Women’s higher education in Japan: Family background, economic factors, and the Equal Employment Opportunity Law.” Journal of the Japanese and International Economies 17, $1-32$.

Genda Yuji. (2003) Who Really Lost Jobs in Japan?: Youth Employment in an Aging 
Japanese Society, In: Labor Markets and Firm Benefit Policies in Japan and the United States, (eds) Seiritsu Ogura, Toshiaki Tachibanaki, and David Wise, The University of Chicago Press, Chicago, 103-133.

Genda, Yuji. (2006) "Inequality of middle-aged non-workers” (Chuunenrei mugyosha kara mita kakusa mondai) In: Henka suru shakaino hubyoudo [Inequality in a changing society] ed. Sawako Shirahase, University of Tokyo Press, 79-104 (in Japanese).

Goldin, Claudia. (1989) "Life-cycle Labor Force Participation of Married Women: Historical Evidence and Implications," Journal of Labor Economics 7(1), 20-47. Hori, Haruhiko. (1998) "Narrowing Gap: Trends in the Gender Wage Differential in Japan” [Danjyokan chingin kakusa no shukusho keiko to sono yoin] Japanese Journal of Labour Studies 456, 41-51 (in Japanese).

Hunt, Jennifer. (2002) “The Transition in East Germany: When Is a Ten-Point Fall in the Gender Wage Gap Bad News?” Journal of Labor Economics 20(1), 148-169.

Juhn, Chinhui, Kevin M. Murphy, and Brooks Pierce. (1991) “Accounting for the Slowdown in Black-White Wage Convergence.” In: Workers and Their Wages, ed. Marvin Kosters, Washington, DC: AEI Press 107-43.

Kambayashi, Ryo, Daiji Kawaguchi, and Izumi Yokoyama. (2008) "Wage Distribution in Japan: 1989-2003.” Canadian Journal of Economics 41(4), 1329-1350.

Kawaguchi, Akira. (2005) "Factors for the narrowing male-female wage gap in the 1990s” [1990 nendai ni okeru Danjo-kan Chingin Kakusa Shukusho no Yoin], Economic Analysis [Keizai Bunseki], Vol.175, Cabinet Office of Japan, Tokyo (in Japanese).

Kawaguchi, Daiji, and Hisahiro Naito. (2006) “The Bound Estimate of the Gender 
Wage Convergence under Employment Compositional Change,” ESRI Discussion Paper 161.

Mulligan, Casey and Yona Rubinstein. (2008) “Selection, investment, and women’s relative wages over time.” Quarterly Journal of Economics 123(3), 1061-1110.

Olivetti, Claudia and Barbara Petrongolo. (2008) Unequal Pay or Unequal Employment? A Cross-Country Analysis of Gender Gaps. Journal of Labor Economics 26(4), 621-654.

O’Neill, June, and Solomon Polachek. (1993) "Why the Gender Gap in Wages Narrowed in the 1980s.” Journal of Labor Economics, 11(1), Part 1, 205-228. 
Table 1

Effects of cohort, age, and education on gender wage gap

Dependent variable: Female-Male wage gap in the base hourly wage

\begin{tabular}{|c|c|c|c|c|c|c|}
\hline & $(1)$ & (2) & (3) & (4) & $(5)$ & $(6)$ \\
\hline $\begin{array}{l}\text { Education level of the } \\
\text { sample }\end{array}$ & ALL & ALL & Junior High & Senior High & Junior College & University \\
\hline Dummy for born & $0.127^{\star \star}$ & $0.079^{\star \star}$ & $0.080^{* \star}$ & $0.091^{\star \star}$ & $0.045^{\star \star}$ & $0.049^{\star \star}$ \\
\hline 1941-1945 & $(0.027)$ & (0.011) & $(0.007)$ & $(0.011)$ & $(0.014)$ & $(0.016)$ \\
\hline Dummy for born & $0.084^{* *}$ & $0.052^{\star *}$ & $0.045^{\star \star}$ & $0.056^{\star \star}$ & $0.052^{\star \star}$ & $0.043^{*}$ \\
\hline $1946-1950$ & (0.025) & $(0.008)$ & $(0.007)$ & $(0.009)$ & $(0.011)$ & (0.018) \\
\hline Dummy for born & 0.043 & $0.025^{\star \star *}$ & $0.016^{*}$ & $0.028^{\star \star}$ & 0.025 & 0.010 \\
\hline 1951-1955 & $(0.024)$ & (0.009) & (0.007) & (0.010) & $(0.017)$ & $(0.016)$ \\
\hline Dummy for born & -0.014 & -0.007 & -0.005 & -0.010 & -0.002 & 0.007 \\
\hline 1961-1965 & (0.025) & $(0.008)$ & (0.018) & (0.010) & $(0.009)$ & (0.015) \\
\hline Dummy for born & -0.025 & -0.013 & -0.005 & -0.014 & -0.009 & -0.001 \\
\hline 1966-1970 & (0.026) & (0.009) & $(0.020)$ & (0.015) & $(0.013)$ & (0.013) \\
\hline Dummy for born & -0.030 & -0.013 & -0.013 & -0.014 & -0.015 & 0.008 \\
\hline 1971-1975 & (0.026) & (0.010) & $(0.012)$ & (0.013) & (0.010) & (0.013) \\
\hline Dummy for born & -0.032 & -0.006 & $-0.038^{\star *}$ & -0.010 & -0.009 & \\
\hline 1976-1980 & (0.028) & (0.014) & $(0.007)$ & (0.015) & (0.011) & \\
\hline Dummy for Age 20-24 & $-0.187^{\star \star}$ & $-0.226^{\star *}$ & $-0.154^{\star *}$ & $-0.244^{\star *}$ & $-0.221^{\star \star}$ & \\
\hline & $(0.024)$ & $(0.010)$ & $(0.011)$ & $(0.010)$ & $(0.011)$ & \\
\hline Dummy for Age 25-29 & $\begin{array}{r}-0.154^{* *} \\
(0.025)\end{array}$ & $\begin{array}{r}-0.153^{* *} \\
(0.007)\end{array}$ & $\begin{array}{r}-0.098^{\star \star} \\
(0.008)\end{array}$ & $\begin{array}{r}-0.175^{\star *} \\
(0.006)\end{array}$ & $\begin{array}{r}-0.176^{\star *} \\
(0.007)\end{array}$ & $\begin{array}{r}-0.131^{\star \star} \\
(0.019)\end{array}$ \\
\hline Dummy for Age 30-34 & $\begin{array}{r}-0.093^{* *} \\
(0.026)\end{array}$ & $\begin{array}{r}-0.092^{* *} \\
(0.007)\end{array}$ & $\begin{array}{r}-0.038^{\star *} \\
(0.004)\end{array}$ & $\begin{array}{r}-0.106^{* *} \\
(0.007)\end{array}$ & $\begin{array}{r}-0.113^{\star *} \\
(0.009)\end{array}$ & $\begin{array}{r}-0.089^{\star \star *} \\
(0.019)\end{array}$ \\
\hline Dummy for Age 35-39 & $\begin{array}{l}-0.039 \\
(0.027)\end{array}$ & $\begin{array}{r}-0.038 \text { ** } \\
(0.008)\end{array}$ & $\begin{array}{r}-0.016^{\star *} \\
(0.005)\end{array}$ & $\begin{array}{r}-0.037^{\star *} \\
(0.008)\end{array}$ & $\begin{array}{r}-0.057^{* *} \\
(0.012)\end{array}$ & $\begin{array}{l}-0.048^{*} \\
(0.019)\end{array}$ \\
\hline Dummy for Age 45-49 & $\begin{array}{r}0.018 \\
(0.026)\end{array}$ & $\begin{array}{r}0.019^{*} \\
(0.009)\end{array}$ & $\begin{array}{r}-0.003 \\
(0.005)\end{array}$ & $\begin{array}{r}0.017 \\
(0.009)\end{array}$ & $\begin{array}{c}0.022^{*} \\
(0.009)\end{array}$ & $\begin{array}{r}0.044 \\
(0.025)\end{array}$ \\
\hline Dummy for Age 50-54 & $\begin{array}{r}0.016 \\
(0.028)\end{array}$ & $\begin{array}{r}0.017 \\
(0.014)\end{array}$ & $\begin{array}{r}-0.024^{\star *} \\
(0.005)\end{array}$ & $\begin{array}{r}0.022 \\
(0.014)\end{array}$ & $\begin{array}{r}0.022 \\
(0.026)\end{array}$ & $\begin{array}{c}0.048^{*} \\
(0.021)\end{array}$ \\
\hline Junior High & & $\begin{array}{l}0.062^{\star *} \\
(0.008)\end{array}$ & & & & \\
\hline Junior College & & $\begin{array}{r}-0.105^{* *} \\
(0.005)\end{array}$ & & & & \\
\hline University & & $\begin{array}{r}-0.148^{* *} \\
(0.006) \\
\end{array}$ & & & & \\
\hline $\begin{array}{l}\text { Number of } \\
\text { Observations }\end{array}$ & 146 & 146 & 38 & 38 & 38 & 31 \\
\hline R-squared & 0.707 & 0.969 & 0.979 & 0.989 & 0.976 & 0.949 \\
\hline
\end{tabular}

Notes:

Robust standard errors in parentheses.

* significant at the $5 \%$ level; ** significant at the $1 \%$ level.

The wage measure of the dependent variable does not include bonuses.

Regressions are estimated by weighted least squares, using the hours worked by workers

in each cell as weights.

The base group for cohort dummies is the cohort born in 1956-60.

The base group for age dummies is those aged 40-44.

The base group for education is senior high school graduates.

Source: Author's calculation from the BSWS. 
Table 2

Effects of cohort, age, and education on gender wage gap (includes tenure ratio as a regressor)

Dependent variable: Female-Male wage gap in the base hourly wage

\begin{tabular}{|c|c|c|c|c|}
\hline & (1) & (2) & (3) & (4) \\
\hline $\begin{array}{l}\text { Education level of the } \\
\text { sample }\end{array}$ & Junior High & Senior High & Junior College & University \\
\hline Dummy for born & $0.089^{\star \star}$ & $0.061^{\star \star}$ & 0.041 & $0.049^{\star}$ \\
\hline 1941-1945 & $(0.019)$ & $(0.018)$ & $(0.026)$ & $(0.017)$ \\
\hline Dummy for born & $0.052^{\star \star *}$ & $0.033^{\star}$ & 0.048 & $0.043^{*}$ \\
\hline 1946-1950 & $(0.014)$ & $(0.013)$ & $(0.023)$ & $(0.018)$ \\
\hline Dummy for born & $0.019 *$ & 0.014 & 0.022 & 0.010 \\
\hline 1951-1955 & $(0.009)$ & $(0.009)$ & $(0.015)$ & $(0.016)$ \\
\hline Dummy for born & -0.008 & -0.003 & -0.002 & 0.007 \\
\hline 1961-1965 & $(0.020)$ & $(0.009)$ & $(0.009)$ & $(0.017)$ \\
\hline Dummy for born & -0.005 & -0.003 & -0.008 & -0.001 \\
\hline $1966-1970$ & $(0.019)$ & $(0.016)$ & (0.013) & $(0.017)$ \\
\hline Dummy for born & -0.009 & -0.004 & -0.016 & 0.008 \\
\hline 1971-1975 & $(0.014)$ & $(0.014)$ & $(0.011)$ & $(0.015)$ \\
\hline Dummy for born & -0.028 & -0.011 & -0.010 & \\
\hline 1976-1980 & $(0.018)$ & $(0.018)$ & $(0.013)$ & \\
\hline Female mean tenure/ & 0.043 & -0.202 & -0.030 & 0.007 \\
\hline Male mean tenure & $(0.083)$ & $(0.104)$ & $(0.185)$ & $(0.075)$ \\
\hline Number of Observations & 38 & 38 & 38 & 31 \\
\hline $\mathrm{R}$-squared & 0.980 & 0.991 & 0.976 & 0.949 \\
\hline
\end{tabular}

Notes:

Robust standard errors in parentheses.

* significant at the $5 \%$ level; ${ }^{* *}$ significant at the $1 \%$ level.

Age dummies are included in each regression, but the coefficients are not shown. The wage measure of the dependent variable does not include bonuses.

Regressions are estimated by weighted least squares, using the hours worked by workers in each cell as weights.

The base group for cohort dummies is the cohort born in 1956-60.

Source: Author's calculation from the BSWS. 
Table 3

Effects of cohort, age, and education on gender employment gap

Dependent variable: Gap in the regular employment ratio (RERGap)

\begin{tabular}{|c|c|c|c|c|c|c|}
\hline & (1) & (2) & (3) & (4) & (5) & (6) \\
\hline $\begin{array}{l}\text { Education level of the } \\
\text { sample }\end{array}$ & ALL & ALL & Junior High & Senior High & Junior College & University \\
\hline Dummy for born & 0.001 & $-0.042^{*}$ & $-0.055^{\star}$ & -0.024 & $0.050^{\star \star}$ & 0.030 \\
\hline $1943-1947$ & $(0.020)$ & $(0.017)$ & $(0.024)$ & $(0.016)$ & $(0.016)$ & $(0.015)$ \\
\hline Dummy for born & -0.002 & $-0.034^{*}$ & -0.040 & -0.022 & 0.017 & -0.004 \\
\hline 1948-1952 & $(0.020)$ & $(0.014)$ & $(0.021)$ & $(0.017)$ & $(0.011)$ & $(0.015)$ \\
\hline Dummy for born & -0.006 & -0.019 & -0.030 & -0.014 & 0.008 & -0.006 \\
\hline 1953-1957 & $(0.021)$ & $(0.013)$ & $(0.025)$ & (0.018) & $(0.017)$ & $(0.018)$ \\
\hline Dummy for born & -0.031 & -0.026 & 0.002 & -0.026 & 0.009 & $-0.051^{*}$ \\
\hline 1963-1967 & $(0.028)$ & $(0.015)$ & $(0.017)$ & (0.018) & (0.013) & $(0.020)$ \\
\hline Dummy for born & -0.057 & $-0.044^{*}$ & 0.024 & -0.041 & -0.022 & $-0.082^{\star *}$ \\
\hline 1968-1972 & $(0.034)$ & $(0.017)$ & $(0.019)$ & $(0.020)$ & $(0.017)$ & $(0.019)$ \\
\hline Dummy for born & -0.063 & -0.040 & $0.046 *$ & -0.019 & -0.020 & -0.096 ** \\
\hline $1973-1977$ & $(0.043)$ & $(0.021)$ & $(0.017)$ & $(0.024)$ & $(0.026)$ & $(0.022)$ \\
\hline Dummy for born & -0.054 & -0.024 & 0.102 & 0.062 & -0.056 & \\
\hline 1978-1982 & $(0.080)$ & $(0.051)$ & $(0.049)$ & $(0.057)$ & $(0.028)$ & \\
\hline Dummy for Age 20-24 & $\begin{array}{r}-0.373^{\star *} \\
(0.045)\end{array}$ & $\begin{array}{r}-0.414^{\star \star} \\
(0.034)\end{array}$ & $\begin{array}{r}-0.100 * \star \\
(0.025)\end{array}$ & $\begin{array}{r}-0.446 * \star \\
(0.028)\end{array}$ & $\begin{array}{r}-0.488^{\star *} \\
(0.023)\end{array}$ & \\
\hline Dummy for Age 25-29 & $\begin{array}{r}-0.138 * \star \\
(0.037)\end{array}$ & $\begin{array}{r}-0.144^{\star \star} \\
(0.018)\end{array}$ & $\begin{array}{r}0.008 \\
(0.020)\end{array}$ & $\begin{array}{r}-0.115^{\star \star} \\
(0.022)\end{array}$ & $\begin{array}{r}-0.201 * \star \\
(0.017)\end{array}$ & $\begin{array}{r}-0.190 * * \\
(0.025)\end{array}$ \\
\hline Dummy for Age 30-34 & $\begin{array}{r}0.026 \\
(0.025)\end{array}$ & $\begin{array}{r}0.022 \\
(0.012)\end{array}$ & $\begin{array}{l}0.051^{*} \\
(0.021)\end{array}$ & $\begin{array}{r}0.031 \\
(0.018)\end{array}$ & $\begin{array}{r}0.015 \\
(0.015)\end{array}$ & $\begin{array}{r}-0.007 \\
(0.019)\end{array}$ \\
\hline Dummy for Age 35-39 & $\begin{array}{r}0.033 \\
(0.018)\end{array}$ & $\begin{array}{l}0.030^{*} \\
(0.012)\end{array}$ & $\begin{array}{r}0.030 \\
(0.024)\end{array}$ & $\begin{array}{r}0.034 \\
(0.017)\end{array}$ & $\begin{array}{l}0.038^{\star *} \\
(0.010)\end{array}$ & $\begin{array}{r}0.012 \\
(0.015)\end{array}$ \\
\hline Dummy for Age 45-49 & $\begin{array}{l}-0.033^{\star} \\
(0.014)\end{array}$ & $\begin{array}{l}-0.032^{*} \\
(0.014)\end{array}$ & $\begin{array}{l}-0.040 \\
(0.022)\end{array}$ & $\begin{array}{l}-0.033^{*} \\
(0.013)\end{array}$ & $\begin{array}{l}-0.028^{\star} \\
(0.011)\end{array}$ & $\begin{array}{r}-0.021 \\
(0.013)\end{array}$ \\
\hline Dummy for Age 50-54 & $\begin{array}{r}-0.019 \\
(0.017)\end{array}$ & $\begin{array}{r}-0.016 \\
(0.013)\end{array}$ & $\begin{array}{l}-0.002 \\
(0.018)\end{array}$ & $\begin{array}{r}-0.009 \\
(0.013)\end{array}$ & $\begin{array}{r}-0.064^{\star *} \\
(0.014)\end{array}$ & $\begin{array}{l}-0.043^{*} \\
(0.020)\end{array}$ \\
\hline Junior High & & $\begin{array}{r}0.038 \\
(0.021)\end{array}$ & & & & \\
\hline Junior College & & $\begin{array}{r}-0.114^{\star *} \\
(0.012)\end{array}$ & & & & \\
\hline University & & $\begin{array}{r}-0.146^{\star *} \\
(0.013)\end{array}$ & & & & \\
\hline Constant & $\begin{array}{l}0.658 * \star \\
(0.019)\end{array}$ & $\begin{array}{l}0.707^{* *} \\
(0.012)\end{array}$ & $\begin{array}{l}0.699 * \star \\
(0.021)\end{array}$ & $\begin{array}{l}0.693^{* *} \\
(0.014)\end{array}$ & $\begin{array}{l}0.597^{\star \star} \\
(0.013)\end{array}$ & $\begin{array}{l}0.596 * \star \\
(0.013)\end{array}$ \\
\hline Number of & 120 & 120 & 31 & 31 & 31 & 26 \\
\hline R-squared & 0.704 & 0.873 & 0.856 & 0.980 & 0.991 & 0.964 \\
\hline
\end{tabular}

Notes:

Robust standard errors in parentheses.

* significant at the $5 \%$ level; ** significant at the $1 \%$ level.

Regressions are estimated by weighted least squares, using the population in each cell as weights.

The base group for cohort dummies is the cohort born in 1958-1962.

The base group for age dummies is those aged 40-44.

The base group for education is senior high school graduates.

Source: Author's calculation from the ESS. 
Table 4

Decomposition of gender wage gap into educational composition and within-education gender gap

\begin{tabular}{lcrrr}
\hline Birth Year & Age & EducComp & WithinGap & Share of EducComp \\
\hline $1946-1950$ & $25-29$ & 0.023 & 0.215 & 0.097 \\
$1946-1950$ & $30-34$ & 0.052 & 0.297 & 0.148 \\
$1946-1950$ & $35-39$ & 0.080 & 0.330 & 0.195 \\
$1946-1950$ & $40-44$ & 0.098 & 0.347 & 0.221 \\
$1946-1950$ & $45-49$ & 0.101 & 0.354 & 0.222 \\
$1946-1950$ & $50-54$ & 0.100 & 0.347 & 0.224 \\
$1946-1950$ & $55-59$ & 0.098 & 0.329 & 0.229 \\
\hline $1951-1955$ & $25-29$ & 0.022 & 0.181 & 0.107 \\
$1951-1955$ & $30-34$ & 0.051 & 0.242 & 0.175 \\
$1951-1955$ & $35-39$ & 0.078 & 0.292 & 0.211 \\
$1951-1955$ & $40-44$ & 0.090 & 0.310 & 0.226 \\
$1951-1955$ & $45-49$ & 0.096 & 0.317 & 0.234 \\
$1951-1955$ & $50-54$ & 0.107 & 0.333 & 0.243 \\
\hline $1956-1960$ & $25-29$ & 0.032 & 0.129 & 0.199 \\
$1956-1960$ & $30-34$ & 0.065 & 0.197 & 0.247 \\
$1956-1960$ & $35-39$ & 0.086 & 0.238 & 0.265 \\
$1956-1960$ & $40-44$ & 0.106 & 0.249 & 0.299 \\
$1956-1960$ & $45-49$ & 0.136 & 0.278 & 0.328 \\
\hline $1961-1965$ & $25-29$ & 0.040 & 0.124 & 0.243 \\
$1961-1965$ & $30-34$ & 0.051 & 0.171 & 0.230 \\
$1961-1965$ & $35-39$ & 0.077 & 0.202 & 0.276 \\
$1961-1965$ & $40-44$ & 0.117 & 0.244 & 0.325 \\
\hline $1966-1970$ & $25-29$ & 0.029 & 0.111 & 0.208 \\
$1966-1970$ & $30-34$ & 0.046 & 0.141 & 0.248 \\
$1966-1970$ & $35-39$ & 0.071 & 0.191 & 0.272 \\
\hline $1971-1975$ & $25-29$ & 0.018 & 0.101 & 0.155 \\
$1971-1975$ & $30-34$ & 0.035 & 0.143 & 0.195 \\
\hline & & & &
\end{tabular}

Note: Decompositon based on Eq. (6) in the text.

Source: Author's calculation from the BSWS. 
Table 5

Decomposition of gender wage convergence into changes in educational compositio and changes in within-education gender gap

\begin{tabular}{llrrr}
\hline Birth Year & Age & $\Delta$ EducComp & $\Delta$ WithinGap & $\Delta$ WageGap \\
\hline $1946-1950$ & $30-34$ & 0.019 & -0.037 & -0.017 \\
$1946-1950$ & $35-39$ & 0.007 & -0.054 & -0.047 \\
$1946-1950$ & $40-44$ & 0.010 & -0.050 & -0.041 \\
$1946-1950$ & $45-49$ & 0.000 & -0.032 & -0.032 \\
$1946-1950$ & $50-54$ & 0.006 & -0.040 & -0.035 \\
$1946-1950$ & $55-59$ & 0.019 & -0.017 & 0.002 \\
\hline $1951-1955$ & $25-29$ & -0.002 & -0.035 & -0.036 \\
$1951-1955$ & $30-34$ & 0.000 & -0.055 & -0.055 \\
$1951-1955$ & $35-39$ & -0.002 & -0.038 & -0.040 \\
$1951-1955$ & $40-44$ & -0.008 & -0.037 & -0.045 \\
$1951-1955$ & $45-49$ & -0.005 & -0.038 & -0.043 \\
$1951-1955$ & $50-54$ & 0.007 & -0.013 & -0.006 \\
\hline $1956-1960$ & $25-29$ & 0.010 & -0.051 & -0.041 \\
$1956-1960$ & $30-34$ & 0.013 & -0.045 & -0.032 \\
$1956-1960$ & $35-39$ & 0.008 & -0.054 & -0.047 \\
$1956-1960$ & $40-44$ & 0.016 & -0.061 & -0.045 \\
$1956-1960$ & $45-49$ & 0.039 & -0.039 & 0.000 \\
\hline $1961-1965$ & $25-29$ & 0.008 & -0.005 & 0.003 \\
$1961-1965$ & $30-34$ & -0.014 & -0.026 & -0.040 \\
$1961-1965$ & $35-39$ & -0.009 & -0.036 & -0.044 \\
$1961-1965$ & $40-44$ & 0.011 & -0.005 & 0.007 \\
\hline $1966-1970$ & $25-29$ & -0.011 & -0.013 & -0.024 \\
$1966-1970$ & $30-34$ & -0.004 & -0.030 & -0.034 \\
$1966-1970$ & $35-39$ & -0.006 & -0.011 & -0.017 \\
\hline $1971-1975$ & $25-29$ & -0.011 & -0.011 & -0.022 \\
$1971-1975$ & $30-34$ & -0.012 & 0.002 & -0.010 \\
\hline
\end{tabular}

Note: Decompositon based on Eq. (7) in the text.

Source: Author's calculation from the BSWS. 
Table A1

Female-Male wage gap in hourly wage (including bonuses)

\begin{tabular}{|c|c|c|c|c|c|c|}
\hline & (1) & (2) & (3) & (4) & (5) & (6) \\
\hline $\begin{array}{l}\text { Education level of the } \\
\text { sample }\end{array}$ & ALL & ALL & Junior High & Senior High & Junior College & University \\
\hline $\begin{array}{l}\text { Dummy for born } \\
1941-1945\end{array}$ & $\begin{array}{l}0.147^{\star \star} \\
(0.026)\end{array}$ & $\begin{array}{l}0.099^{\star \star} \\
(0.012)\end{array}$ & $\begin{array}{l}0.104^{\star \star} \\
(0.007)\end{array}$ & $\begin{array}{l}0.114^{\star \star} \\
(0.015)\end{array}$ & $\begin{array}{l}0.085^{\star \star} \\
(0.019)\end{array}$ & $\begin{array}{l}0.061^{\star \star} \\
(0.016)\end{array}$ \\
\hline Dummy for born & $0.093^{* *}$ & $0.061^{* *}$ & $0.060^{* *}$ & $0.069 * *$ & $0.075^{* *}$ & 0.033 \\
\hline 1946-1950 & $(0.025)$ & (0.010) & $(0.007)$ & (0.012) & (0.015) & (0.018) \\
\hline Dummy for born & $0.048^{*}$ & $0.030 * *$ & $0.022^{* *}$ & $0.037^{\star \star \star}$ & $0.039^{\star}$ & 0.003 \\
\hline 1951-1955 & (0.023) & $(0.010)$ & $(0.006)$ & $(0.013)$ & $(0.017)$ & $(0.016)$ \\
\hline Dummy for born & -0.013 & -0.006 & -0.001 & -0.005 & 0.009 & -0.008 \\
\hline $1961-1965$ & $(0.024)$ & $(0.010)$ & $(0.018)$ & $(0.013)$ & $(0.013)$ & $(0.016)$ \\
\hline Dummy for born & -0.021 & -0.008 & 0.011 & -0.004 & -0.003 & -0.006 \\
\hline $1966-1970$ & (0.026) & (0.011) & $(0.019)$ & (0.018) & (0.016) & (0.015) \\
\hline Dummy for born & -0.020 & $-5 . E-04$ & 0.012 & 0.004 & -0.001 & 0.008 \\
\hline $1971-1975$ & $(0.027)$ & $(0.012)$ & (0.008) & $(0.013)$ & $(0.012)$ & $(0.013)$ \\
\hline Dummy for born & -0.011 & 0.017 & 0.009 & 0.026 & 0.010 & \\
\hline $1976-1980$ & (0.032) & $(0.013)$ & $(0.006)$ & $(0.014)$ & $(0.012)$ & \\
\hline Dummy for Age $20-24$ & $\begin{array}{r}-0.221^{\star \star} \\
(0.025)\end{array}$ & $\begin{array}{r}-0.255^{\star \star} \\
(0.011)\end{array}$ & $\begin{array}{r}-0.184^{\star *} \\
(0.008)\end{array}$ & $\begin{array}{r}-0.277^{* *} \\
(0.012)\end{array}$ & $\begin{array}{r}-0.237^{\star *} \\
(0.014)\end{array}$ & \\
\hline Dummy for Age 25-29 & $\begin{array}{r}-0.182^{\star \star} \\
(0.025)\end{array}$ & $\begin{array}{r}-0.181^{* *} \\
(0.008)\end{array}$ & $\begin{array}{r}-0.118^{\star \star} \\
(0.008)\end{array}$ & $\begin{array}{r}-0.205^{\star *} \\
(0.008)\end{array}$ & $\begin{array}{r}-0.203^{* \star} \\
(0.011)\end{array}$ & $\begin{array}{r}-0.158^{\star *} \\
(0.019)\end{array}$ \\
\hline Dummy for Age 30-34 & $\begin{array}{r}-0.105^{\star \star} \\
(0.025)\end{array}$ & $\begin{array}{r}-0.104^{\star *} \\
(0.008)\end{array}$ & $\begin{array}{r}-0.046^{\star \star} \\
(0.006)\end{array}$ & $\begin{array}{r}-0.119^{* *} \\
(0.009)\end{array}$ & $\begin{array}{r}-0.125^{\star \star} \\
(0.013)\end{array}$ & $\begin{array}{r}-0.101^{\star \star} \\
(0.019)\end{array}$ \\
\hline Dummy for Age 35-39 & $\begin{array}{r}-0.045 \\
(0.027)\end{array}$ & $\begin{array}{r}-0.044^{\star *} \\
(0.008)\end{array}$ & $\begin{array}{r}-0.019^{\star \star} \\
(0.005)\end{array}$ & $\begin{array}{r}-0.044^{* *} \\
(0.009)\end{array}$ & $\begin{array}{r}-0.061^{\star *} \\
(0.015)\end{array}$ & $\begin{array}{l}-0.056^{*} \\
(0.020)\end{array}$ \\
\hline Dummy for Age $45-49$ & $\begin{array}{r}0.017 \\
(0.026)\end{array}$ & $\begin{array}{r}0.017 \\
(0.010)\end{array}$ & $\begin{array}{r}-0.006 \\
(0.006)\end{array}$ & $\begin{array}{r}0.015 \\
(0.012)\end{array}$ & $\begin{array}{r}0.024 \\
(0.023)\end{array}$ & $\begin{array}{r}0.043 \\
(0.026)\end{array}$ \\
\hline Dummy for Age 50-54 & $\begin{array}{r}0.011 \\
(0.030)\end{array}$ & $\begin{array}{r}0.011 \\
(0.016)\end{array}$ & $\begin{array}{r}-0.025^{\star \star} \\
(0.006)\end{array}$ & $\begin{array}{r}0.018 \\
(0.021)\end{array}$ & $\begin{array}{r}0.014 \\
(0.034)\end{array}$ & $\begin{array}{r}0.038 \\
(0.025)\end{array}$ \\
\hline Junior High & & $\begin{array}{l}0.055^{\star *} \\
(0.009)\end{array}$ & & & & \\
\hline Junior College & & $\begin{array}{r}-0.129 * \star \\
(0.006)\end{array}$ & & & & \\
\hline University & & $\begin{array}{r}-0.140 * \star \\
(0.006) \\
\end{array}$ & & & & \\
\hline $\begin{array}{l}\text { Number of } \\
\text { Observations }\end{array}$ & 146 & 146 & 38 & 38 & 38 & 31 \\
\hline R-squared & 0.750 & 0.969 & 0.986 & 0.986 & 0.974 & 0.949 \\
\hline
\end{tabular}

Notes:

Robust standard errors in parentheses.

* significant at the $5 \%$ level; ** significant at the $1 \%$ level.

The wage measure of the dependent variable includes bonuses.

Regressions are estimated by weighted least squares, using the hours worked by workers

in each cell as weights.

The base group for cohort dummies is the cohort born in 1956-60.

The base group for age dummies is those aged 40-44.

The base group for education is senior high school graduates.

Source: Author's calculation from the BSWS. 
Table A2: Educational distribution by birth year groups

Men

\begin{tabular}{lrrrr}
\hline Birth years & Junior High & \multicolumn{1}{c}{ Senior High } & Junior College & University \\
\hline $1946-1950$ & 0.213 & 0.478 & 0.040 & 0.230 \\
$1951-1955$ & 0.157 & 0.474 & 0.052 & 0.282 \\
$1956-1960$ & 0.089 & 0.451 & 0.070 & 0.355 \\
$1961-1965$ & 0.069 & 0.460 & 0.089 & 0.342 \\
$1966-1970$ & 0.078 & 0.447 & 0.110 & 0.317 \\
$1971-1975$ & 0.078 & 0.435 & 0.134 & 0.298 \\
\hline
\end{tabular}

Women

\begin{tabular}{lrrrr}
\hline Birth years & \multicolumn{1}{c}{ Junior High } & \multicolumn{1}{c}{ Senior High } & Junior College & University \\
\hline $1946-1950$ & 0.212 & 0.566 & 0.127 & 0.059 \\
$1951-1955$ & 0.139 & 0.564 & 0.177 & 0.089 \\
$1956-1960$ & 0.068 & 0.517 & 0.258 & 0.127 \\
$1961-1965$ & 0.048 & 0.508 & 0.287 & 0.126 \\
$1966-1970$ & 0.053 & 0.471 & 0.305 & 0.135 \\
$1971-1975$ & 0.055 & 0.408 & 0.335 & 0.163 \\
\hline
\end{tabular}

Note: The figures are the share of population of each educational group for the birth year group. The figures are calculated for those who are aged 25-54 in year 2000.

Source: Census of Japan, 2000 
Figure 1: Gender wage gap for cohorts

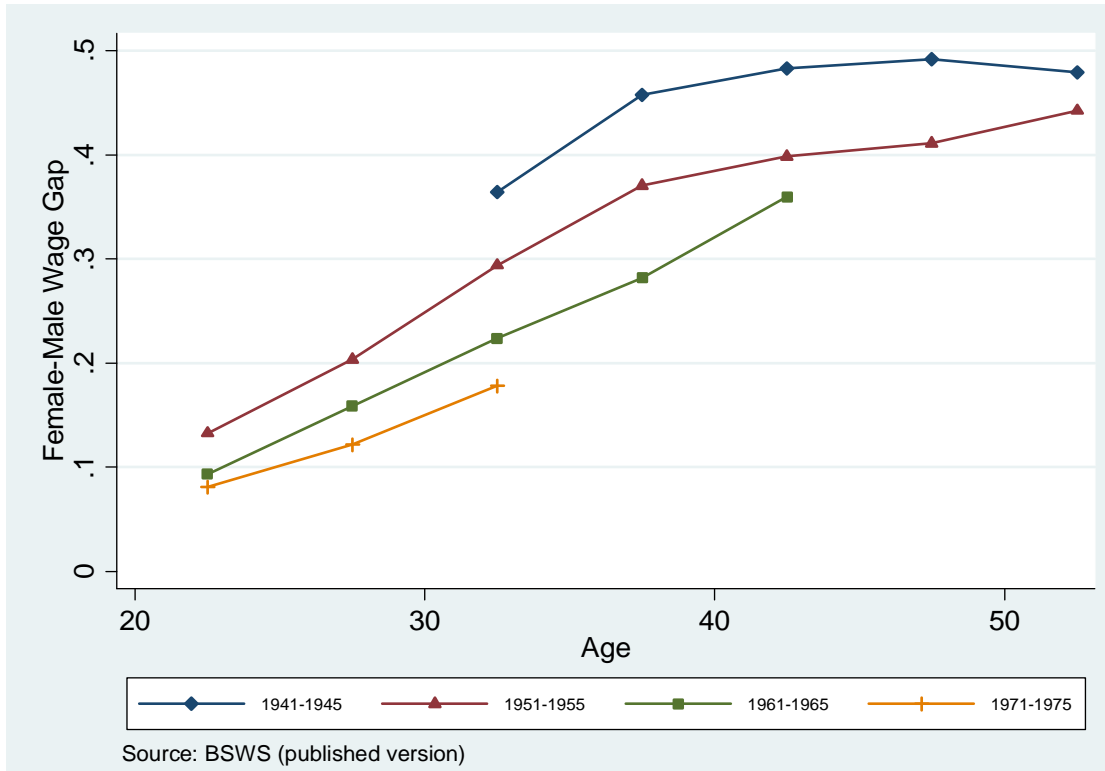

Figure 2: Gender wage gap for cohorts By education

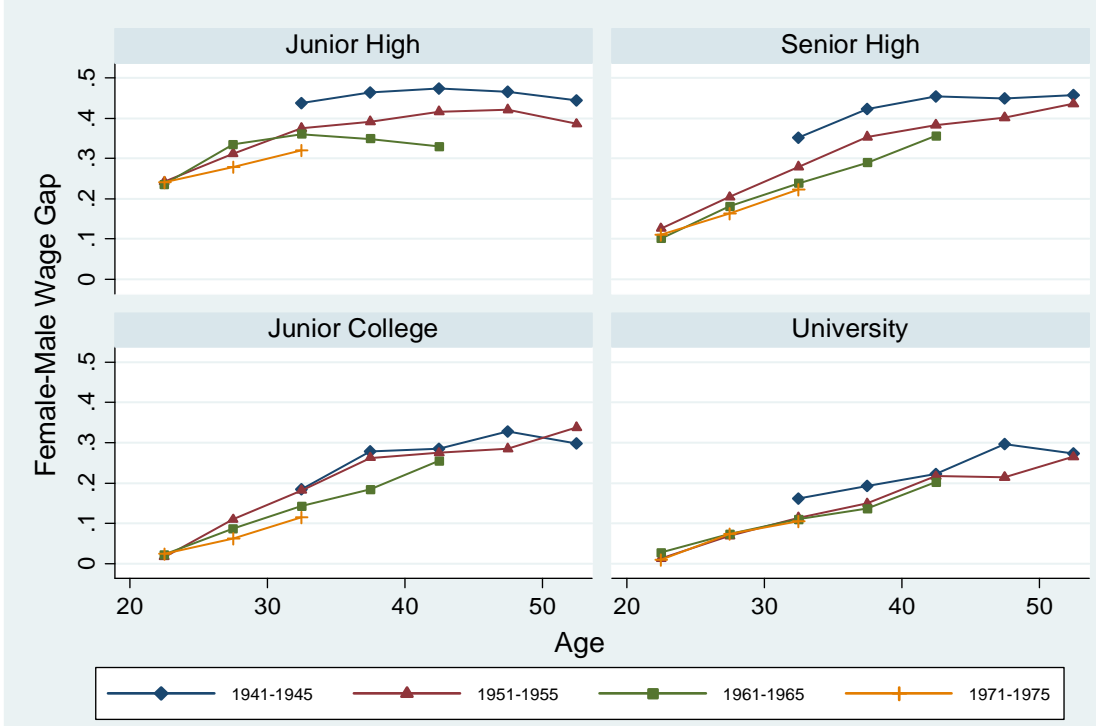

Source: BSWS (published version) 
Figure 3: Gender gap in regular employment for cohorts

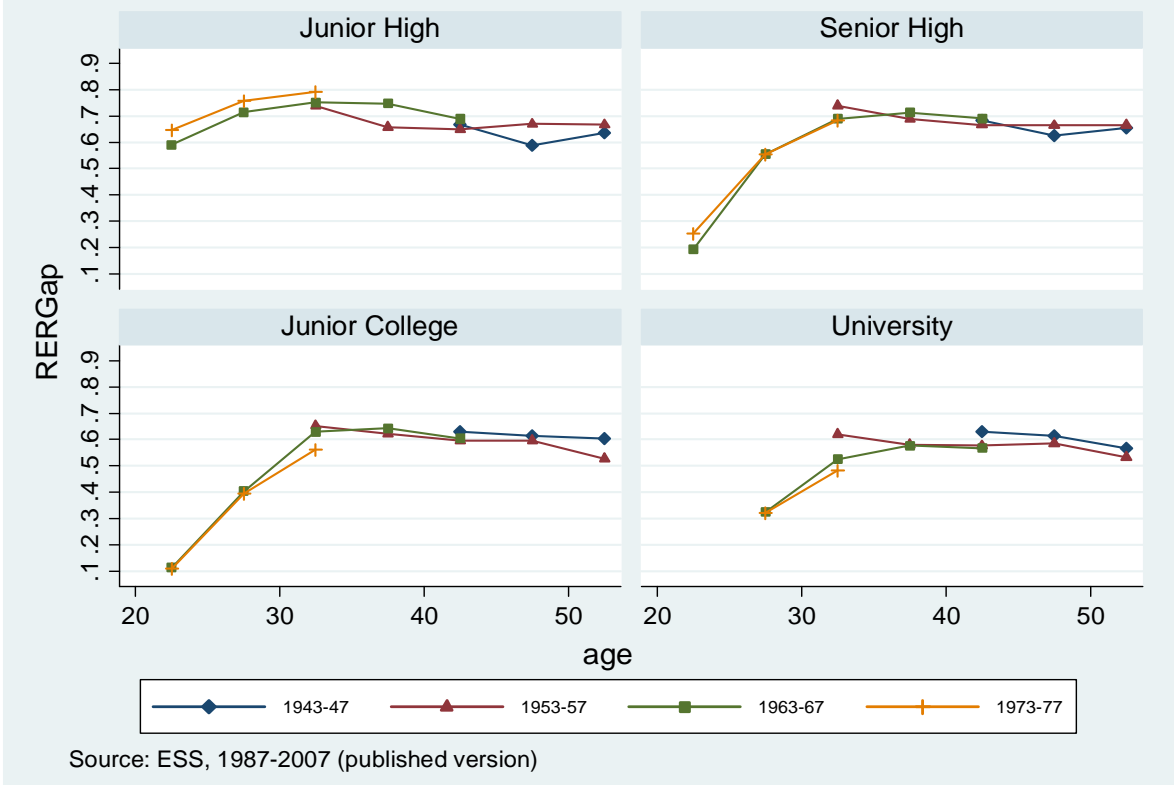

Source: Author's calculation from the ESS. 
Figure 4: Changes in hours share from 1985 to 2005

Male regular employees
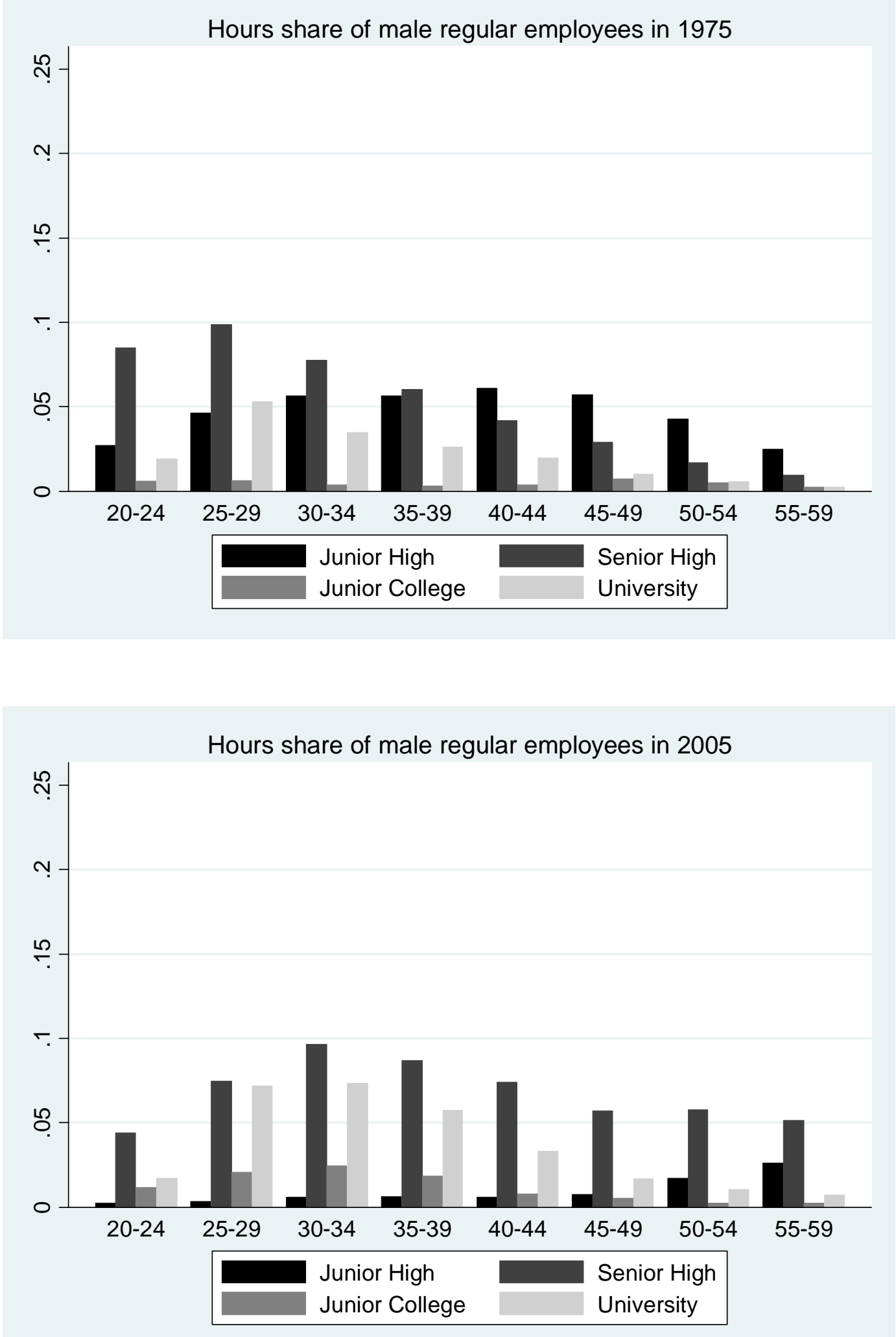

Source: Author's calculation from the Basic Survey of Wage Structure (published version). 
Figure 5: Changes in hours share from 1985 to 2005

Female regular employees
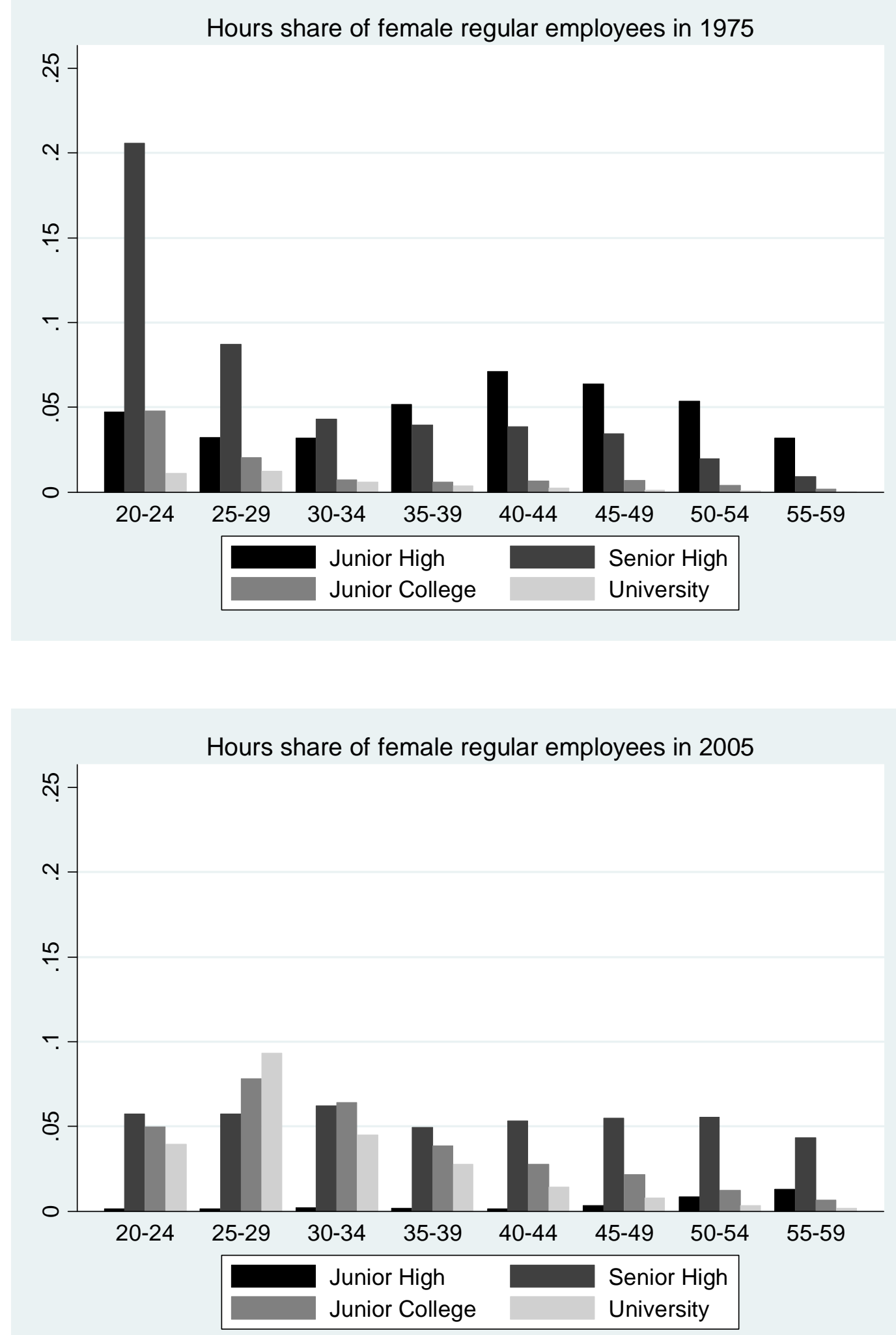

Source: Author's calculation from the Basic Survey of Wage Structure (published version). 